\title{
Risk of genetic vulnerability and aspects of the reproductive biology of Psychotria ipecacuanha (Rubiaceae), a threatened medicinal plant species of Brazilian forests
}

\section{Patrícia Campos da Silva ${ }^{1}$, Talita Oliveira Nascimento ${ }^{1}$ (1), Willian Krause $^{2}$ (D, Douglas Siqueira de Almeida Chaves $^{3}$ (1) and Celice Alexandre Silva ${ }^{1,2 *}$ (1)}

Received: April 2, 2019

Accepted: July 10, 2019

\begin{abstract}
Psychotria ipecacuanha, commonly known as Ipeca, is a medicinal plant of pharmacological and economic value. The species is distylous; it has populations with two floral morphs, one with long and one with short styles. Apart from the presence of two floral morphs in a balanced ratio (1:1), reciprocal herkogamy of the reproductive organs between alternative morphs is desirable to maintain cross-pollination. The risk factors for genetic erosion and conditions for sexual reproduction in natural populations of $P$. ipecacuanha were investigated. The main risks for genetic erosion in four populations studied were: habitat change in the forest fragment where they occurred and in the surrounding area over the last 20 years; proximity to agricultural areas; frequency of drought affecting the forest fragment; and the area occupied by the species within the forest fragment. All evaluated populations were isoplethic with the reciprocity of reproductive organs varying across populations. Anthropogenic factors, associated with morphological and reproductive characteristics (e.g., low reciprocity between anther and stigma and low pollen production), indicate risks for the maintenance and reproduction of Ipeca in the population of the municipality of Denise. Habitat loss, small clusters, and the low number of reproductive plants jeopardize the survival of the studied populations.
\end{abstract}

Keywords: distyly, floral morphs, genetic erosion, Ipeca, reciprocal herkogamy

\section{Introduction}

Genetic erosion can be defined as a permanent reduction in the richness or regularity of local alleles, or the loss of combinations of these alleles in a given area, over the course of time, resulting in a loss of evolutionary potential and a reduction in the direct use of plant and population genetic resources (Maxted et al. 2002).

The rate of species loss far exceeds the origin of new species, and unlike the mass extinctions of species in the past, those occurring currently are mainly results of human activities (Kideghesho et al. 2005). The reproductive system, life cycle, and ploidy level of a species affect the movement of genes and genetic diversity. The issue of genetic erosion is addressed within the main context of the biology of individual species.

Ecogeographic studies collect and synthesize ecological, geographic, and taxonomic information as a way of establishing predictions underlying the formulation of conservation strategies and collection priorities (Crane 2003).

\footnotetext{
1 Programa de Pós-graduação em Genética e Melhoramento de Plantas, Universidade do Estado de Mato Grosso, 78300-000,

2 Centro de Pesquisa, Ensino e Desenvolvimento Agroambiental, Universidade do Estado de Mato Grosso, 78300-000, Tangará da Serra, MT, Brazil 3 Instituto de Ciências Biológicas e da Saúde, Departamento de Ciências Farmacêuticas, Universidade Federal Rural do Rio de Janeiro,

23890-000, Seropédica, RJ, Brazil
}

* Corresponding author: celice@unemat.br 
Psychotria ipecacuanha (Ipeca), a synonym of Carapichea ipecacuanha, see (Andersson 2002), is a distylous shrub found exclusively in shaded forest understories (Oliveira \& Martins 2002). Psychotria ipecacuanha occurs in Central America (e.g., Panama, Nicaragua, and Costa Rica), South America (Colombia), part of the Brazilian Amazon (states of Rondônia and Mato Grosso), and the Atlantic Forest (mainly in the states of Bahia, Espírito Santo, Rio de Janeiro, and Minas Gerais) (Skorupa \& Assis 1998; Assis \& Giulietti 1999). In their natural environment, Ipecas are rarely found as isolated plants, and tend to grow in circular or elliptical clusters.

At the first meeting of the committee of Conservation of Genetic Resources of Medicinal and Aromatic Plants, $P$. ipecacuanha was recognized as a priority for conservation studies (Vieira et al. 2002). In 2013, P. ipecacuanha was considered vulnerable to extinction due to the effects of predatory exploitation, trade, and export, the fragmentation and deforestation of its forest habitat, and due to the requirement for cross-pollination, increasing the rareness of subpopulations and making them prone to deleterious stochastic, genetic, population, and environmental effects (Zappi et al. 2013). The medicinal and economical value of $P$. ipecacuanha is based on the expectorant, amebicidal, and vomitive substances contained in the isoquinolinic alkaloids emetine and cephalin found in the roots (Giraldo et al. 2015).

Distylous species exist in populations with two floral morphs. The pin morph has long pistils and short stamens (called long-styled morphs), while the thrum morph presents short pistils and long stamens (called short-styled morphs) (Ferrero et al. 2009). Apart from the presence of floral morphs in a balanced ratio (1:1), reciprocal herkogamy of the reproductive organs between the alternative morphs (long-styled and short-styled) is desirable for cross pollination. This floral polymorphism is usually accompanied by an intra-morphic autoincompatibility system and a series of accessory floral features, that differ between floral morphs (size of flowers, lobe stigma, number and size of pollen grains; Ganders 1979). Due to the intra-morphological self-incompatibility system, only legitimate pollen from the opposite morph is able to fertilize the ovules and produce viable seeds (Barrett 2002). The reproduction of distylous species also depends on factors related to pollen viability (Silva \& Vieira 2015) and changes in floral morphology, which can affect the position of the reproductive organs (Hodgins \& Barrett 2008).

Based on ecological conditions and habitat requirements for species conservation, our objective was to test the hypothesis that the intensity of anthropogenic disturbance can influence the isopleth, floral morphometry, pollen viability, and population size of four natural Ipeca populations in the southwest region of Mato Grosso, Brazil.

\section{Materials and methods}

Collection expeditions were carried out from October 2015 to October 2016 to seven municipalities in the southeastern region of Mato Grosso - Brazil (Fig. 1) where Ipeca has previously been reported in populations of forest fragments. In only four of these municipalities (Barra do Bugres - BAB; $14^{\circ} 52^{\prime} \mathrm{S} 57^{\circ} 53^{\prime} \mathrm{W}, 263 \mathrm{~m}$ above sea level a.s.l., Denise - DEN; $14^{\circ} 39^{\prime}$ S 57 $05^{\circ} \mathrm{W}, 191 \mathrm{~m}$ a.s.l., Nova Olímpia - NOL; $14^{\circ} 47^{\prime} \mathrm{S} 57^{\circ} 15^{\prime} \mathrm{W}, 181 \mathrm{~m}$ a.s.l., and Tangará da Serra - TGA; $14^{\circ} 38^{\prime} \mathrm{S} 57^{\circ} 19^{\prime} \mathrm{W}, 457 \mathrm{~m}$ a.s.l.) Ipeca populations were found. On a local spatial scale, the distances between the nearest clusters within a given population ranged from 40 to $100 \mathrm{~m}$. Populations of Ipeca with groupings of more than three plants (rametes) in the reproductive phase were evaluated. Voucher specimens (Fig. 2) were deposited in the Herbarium of the State University of Mato Grosso, Brazil (TANG 3290, 3291, 3292, and 3293).

The climate of the region is characterized by two welldefined seasons: rainfall, between October and April, and drought, between June and August. The vegetation is considered a transition from the Amazon Forest to the Cerrado biomes and is currently fragmented due to the implantation of monocultures. Data on forest fragments were obtained by direct observations during expeditions, from conversations with local residents, or surveys exploiting information from the internet, road maps, and institutions.

Five soil samples per population were collected and soil fertility parameters were analyzed. The geographic coordinates and altitude were determined with a GPS device. Rainfall and temperature data were provided by the meteorological institute of Brazil - INMET.

The risk of genetic erosion in P. ipecacuanha was evaluated by a methodology adapted from Oliveira \& Martins (2002). For each forest fragment, the risk of genetic erosion was determined by adding the scores attributed to 20 factors (Tab. 1). A score between 0 and 10 was assigned to each factor. The relative risk was determined by the sum of each risk score of the factor, and is calculated as the percentage in relation to the maximum sum of all factor scores (200 or 100\%) (Tab. 1). The term "agricultural" used for factors F3 and F4 indicates areas used for agriculture and/or livestock husbandry. The term "population center" used for factor F5 (Tab. 1) indicates the city closest to the forest fragment. "Main road" (Factor F6) indicates the nearest state highway (with or without asphalt paving) (Tab. 1). The sum of the scores represents the threat of genetic erosion to which P. ipecacuanha is exposed in the four municipalities analyzed.

To evaluate the ratio between short- and long-styled morphs, flowering plants of both floral morphs were counted and identified in the four studied forest fragments. In each population, the numbers of clusters, area occupied by the 
cluster, total number of plants per population, and number of plants in the reproductive stage per floral morph were observed.

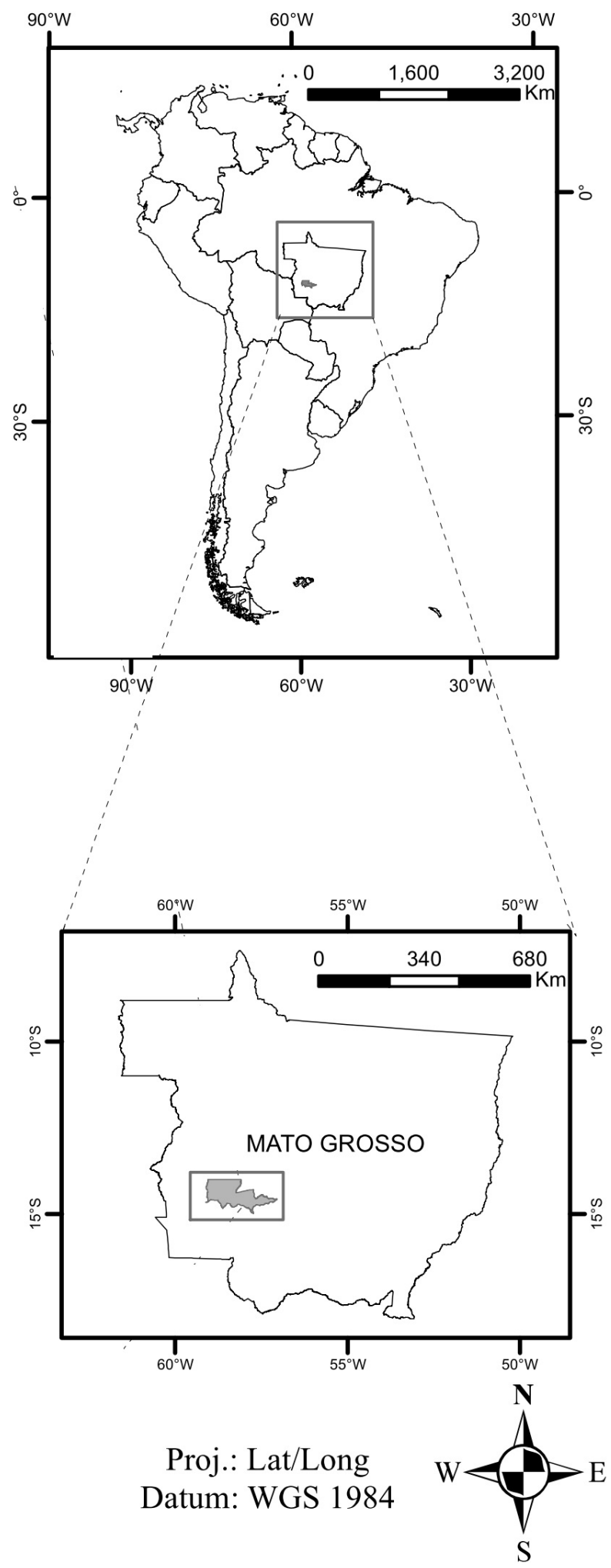

Figure 1. Map showing the study location of Psychotria ipecacuanha, Mato Grosso-Brazil.
The morphometry of short- and long-styled morphs was analyzed. For each morph, five flowers were collected from four plants per population, making a total of 20 flowers per morph/population. The flowers were stored in $70 \%$ alcohol. In the laboratory, using millimeter graph paper and a stereoscope microscope, we measured floral structures were measured using millimeter graph paper and a stereoscope microscope as follows: corolla length (mm); stigma lobe length (mm); anther size (mm); style height ( $\mathrm{mm})$; and stamen height (mm) (Fig. 3).

The reciprocal placement of anthers and stigma was further studied using the reciprocity index developed by Sánchez et al. $(2008 ; 2013)$ by investigating the influence of corolla tube length on the herkogamy of the two floral morphs (Faivre \& McDade 2001). The reciprocity index compares the relative position of the sexual organs (anthers and stigmas) of each flower with the reciprocal organ in the flowers of the alternative morph. The index varies between 0 and 1 (the closer to 1 , the higher the reciprocity). Calculations can be processed with RECIPROCITY, a simple macro for Excel (available at http://webs.uvigo.es/ plantecology/software.es.html).

The viability of pollen grains was evaluated in five pre-anthesis buds of four plants per morph, in all four populations. The buds were stored in $70 \%$ alcohol and all anthers per bud were subsequently mounted on a slide in a drop of acetic carmine. Up to 200 grains per slide were analyzed (Koch et al. 2010).

Pollen production per floral morph of five flowers per morph per population was calculated. One ground anther per flower was mounted on a slide in a drop of acetic carmine and the number of pollen grains was multiplied by the number of anthers per flower (Silva \& Segura 2015).

Stigma receptivity was tested during anthesis in five flowers per morph per population, using hydrogen peroxide (3\%) (Kearns \& Inouye 1993).

Differences in the frequency of floral morphs and pollen production among populations were evaluated by the Chisquare test. To analyze differences in floral structures, the Shapiro Wilk test was performed to verify the normality of errors and the Kruskal-Wallis (non-parametric) test was used to evaluate floral morphometry. In case of significantly different floral structures, the Scott-Knott test was performed. Program R, version 3.3.1 was used to perform the Shapiro-Wilk, Kruskal-Wallis, and Scott-Knott tests (R Development Core Team 2014).

\section{Results}

Annual rainfall varied from 1578 to $1750 \mathrm{~mm}$, and the mean temperature was $22{ }^{\circ} \mathrm{C}$. All populations were found in shaded areas within the forest fragments, on acid, clayey soils rich in organic matter.

The number of $P$. ipecacuanha clusters per population ranged from 4 to 10 . The cluster diameter varied from 0.80 


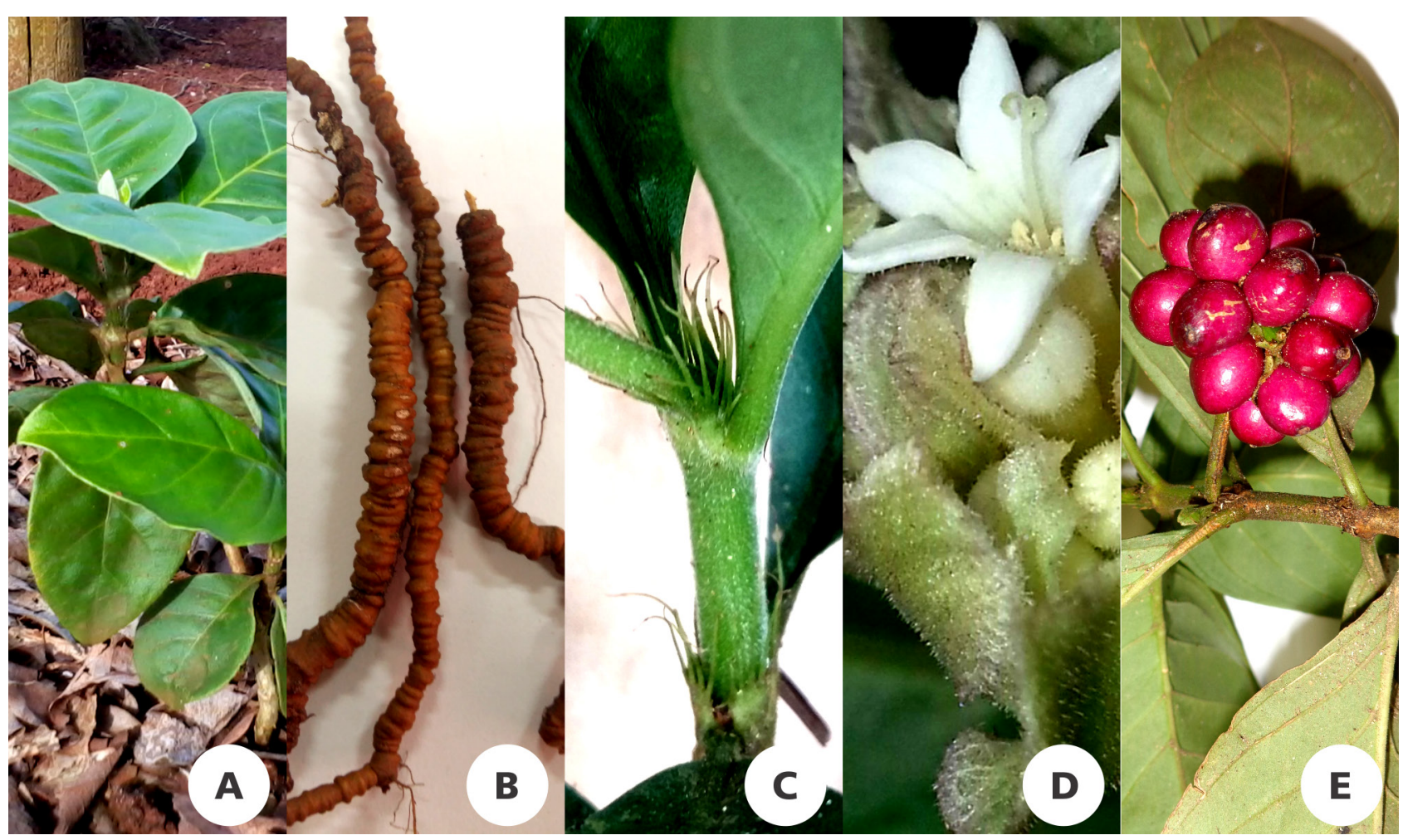

Figure 2. Psychotria ipecacuanha A. Habit B. Rooted roots of ipecac C. Interpetiolar stipules D. Inflorescence E. Ripe Fruit
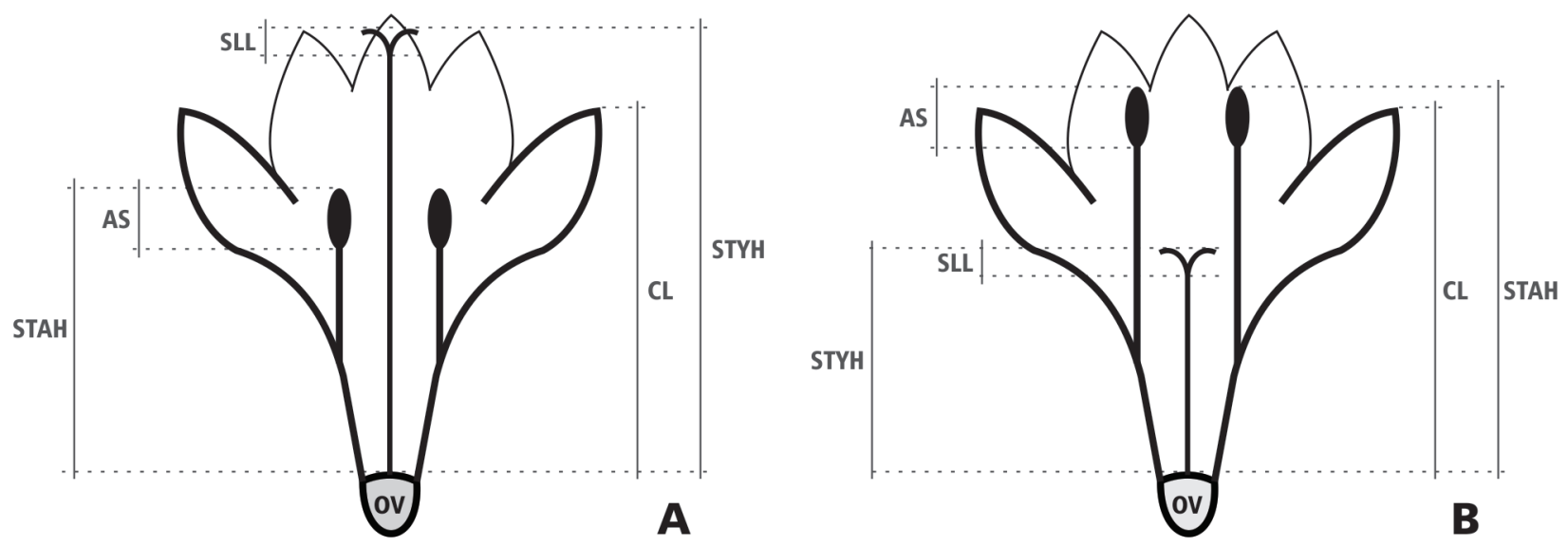

Figure 3. Morphometry ( $\mathrm{mm}$ ) of long styled (A) and short styled (B) flowers of Psychotria ipecacuanha. Corolla Length (CL), Style Height (STYH), Stigmatic Lobe Length (SLL), Stamen Height (STAH) and Anther Size (AS)

$\pm 0.41 \mathrm{~m}^{2}$ (Nova Olímpia) to $3.88 \pm 5.33 \mathrm{~m}^{2}$ (Tangará da Serra) (Tab. 2).

The population from Barra do Bugres had the lowest risk of genetic erosion (43.33\%) (Tab. 3). This population dwells in a preserved forest fragment, which is part of a private property.

The highest risk of genetic erosion was recorded in the population of Denise (Tab. 3). The proximity of the species to the fragment border and the population center, the advance of the agricultural frontier, the occurrence of forest fires, the species' susceptibility to cattle trampling, and fragment size are factors affecting the survival of the P. ipecacuanha population in Denise (Tab. 3).
The main risks of genetic erosion in all four populations studied involved habitat change in the forest fragment and surrounding areas in the past 20 years, proximity to agricultural areas, and the frequency of drought affecting the forest fragment and the area occupied by species within a forest fragment (data not shown). Together, these factors contributed $43 \%$ of the genetic erosion threat in the study populations.

Both floral morphs of $P$. ipecacuanha were found in the studied forest fragments, in a balanced ratio (Tab. 2). A rather low number of reproductive plants was recorded; 90 plants were found in the forest fragment in Denise, 30 


\section{Patrícia Campos da Silva, Talita Oliveira Nascimento, Willian Krause, Douglas Siqueira de Almeida Chaves and Celice Alexandre Silva}

Table 1. Risk factors of genetic erosion of Psychotria ipecacuanha populations assessed in in four forest fragments in the state of Mato Grosso, Brazil. SI = Source of information $(\mathrm{O}=$ direct observation in the study area during collection expeditions, $\mathrm{I}=\mathrm{Interview}$ with local inhabitants, $\mathrm{C}=$ Consultation of available databases).

\begin{tabular}{|c|c|c|c|}
\hline Code & SI & Factors contributing to genetic erosion & Score \\
\hline \multirow[t]{5}{*}{ F1 } & $\mathrm{O}$ & 1. Exploitation level of the wild habitat within the forest fragment & \\
\hline & & Industrial exploitation & 10.00 \\
\hline & & Exploitation by the surrounding populations (e.g., wood collection by neighboring communities) & 6.66 \\
\hline & & Hunting and collection by small local communities & 3.33 \\
\hline & & Fully protected & 0.00 \\
\hline \multirow[t]{4}{*}{ F2 } & $\mathrm{O} / \mathrm{I}$ & 2. Changes in the habitat type in the forest fragment and surrounding areas over the last 20 years & \\
\hline & & Increasing level of disturbance & 10.00 \\
\hline & & No changes & 5.00 \\
\hline & & Decreasing level of disturbance & 0.00 \\
\hline \multirow[t]{4}{*}{ F3 } & C & 3. Availability of agricultural land in surrounding areas & \\
\hline & & $>70 \mathrm{ha} / \mathrm{km} 2$ cultivated area & 10.00 \\
\hline & & $30-70 \mathrm{ha} / \mathrm{km} 2$ cultivated area & 5.00 \\
\hline & & $<30 \mathrm{ha} / \mathrm{km} 2$ cultivated area & 0.00 \\
\hline \multirow[t]{6}{*}{ F4 } & $\mathrm{O} / \mathrm{C}$ & 4. Pressure of surrounding farmland on the forest fragment & \\
\hline & & Large-scale cultivation in the surroundings & 10.00 \\
\hline & & Fields of family agriculture in the surroundings & 7.50 \\
\hline & & Soil suited for cultivation, agricultural fields at a distance of $3 \mathrm{~km}$ from the forest fragment borders. & 5.00 \\
\hline & & Soil suited for cultivation, agricultural fields at a distance of 3-10 km from the forest fragment borders. & 2.50 \\
\hline & & Soil inadequate for cultivation & 0.00 \\
\hline \multirow[t]{4}{*}{ F5 } & $\mathrm{O} / \mathrm{I}$ & 5. Distance of the forest fragment from the largest population center & \\
\hline & & $<20 \mathrm{~km}$ & 10.00 \\
\hline & & $20-50 \mathrm{~km}$ & 5.00 \\
\hline & & $>50 \mathrm{~km}$ & 0.00 \\
\hline \multirow[t]{4}{*}{ F6 } & C & 6. Distance of forest fragment from the main road & \\
\hline & & $<5 \mathrm{~km}$ & 10.00 \\
\hline & & $5-10 \mathrm{~km}$ & 5.00 \\
\hline & & $>10 \mathrm{~km}$ & 0.00 \\
\hline \multirow[t]{4}{*}{ F7 } & $\mathrm{O} / \mathrm{C}$ & $\begin{array}{l}\text { 7. Distance of forest fragment from new development projects (irrigation system, touristic complex, } \\
\text { mining site, hydroelectric power system, and areas destined for agrarian reform) }\end{array}$ & \\
\hline & & $<5 \mathrm{~km}$ & 10.00 \\
\hline & & $5-30 \mathrm{~km}$ & 5.00 \\
\hline & & $>30 \mathrm{~km}$ & 0.00 \\
\hline \multirow[t]{4}{*}{ F8 } & $\mathrm{O} / \mathrm{I}$ & 8. Frequency of drought affecting the forest fragment & \\
\hline & & Known to have occurred in two or more subsequent years & 10.00 \\
\hline & & Mean occurrence once or more in 10 years, but not in consecutive years & 5.00 \\
\hline & & Mean occurrence less than once in 10 years & 0.00 \\
\hline \multirow[t]{4}{*}{ F9 } & I & 9. Accidental fire in the forest fragment & \\
\hline & & Small forest fragment, known as fire-prone & 10.00 \\
\hline & & Large forest fragment, known as fire-prone & 5.00 \\
\hline & & Area not known as fire-prone & 0.00 \\
\hline \multirow[t]{4}{*}{ F10 } & C & 10. Estimated area of the forest fragment where the species was found & \\
\hline & & $<5$ ha & 10.00 \\
\hline & & $5-100$ ha & 5.00 \\
\hline & & $>100$ ha & 0.00 \\
\hline \multirow[t]{5}{*}{ F11 } & $\mathrm{O}$ & 11. Distribution of the target species & \\
\hline & & Limited and rare distribution within forest fragment & 10.00 \\
\hline & & Limited but common distribution within the forest fragment & 6.66 \\
\hline & & Generalized, but rare at the site of occurrence & 3.33 \\
\hline & & Abundant and widely distribuited & 0.00 \\
\hline \multirow[t]{5}{*}{ F12 } & $\mathrm{O}$ & 12. Extension of the wild habitat of the target species within the forest fragment & \\
\hline & & Very limited (5\%) & 10.00 \\
\hline & & Limited (5-15\%) & 6.66 \\
\hline & & $15-50 \%$ & 3.33 \\
\hline & & Wide $(0.50 \%)$ & 0.00 \\
\hline
\end{tabular}


Risk of genetic vulnerability and aspects of the reproductive biology of Psychotria ipecacuanha (Rubiaceae), a threatened medicinal plant species of Brazilian forests

Table 1. Cont.

\begin{tabular}{|c|c|c|c|}
\hline Code & SI & Factors contributing to genetic erosion & Score \\
\hline \multirow[t]{4}{*}{ F13 } & $\mathrm{O}$ & 13. Distance of the site where the target species was found from the border of the forest fragment & \\
\hline & & $<10 \mathrm{~m}$ & 10.00 \\
\hline & & $10-50 \mathrm{~m}$ & 5.00 \\
\hline & & $>50 \mathrm{~m}$ & 0.00 \\
\hline \multirow[t]{5}{*}{ F14 } & $\mathrm{O}$ & 14. Susceptibility of the target species to animal grazing & \\
\hline & & High, including signs of herbivoria & 10.00 \\
\hline & & High, but no sign of herbivory found & 6.66 \\
\hline & & Low, signs of herbivory found & 3.33 \\
\hline & & Low, no sign of herbivory found & 0.00 \\
\hline \multirow[t]{4}{*}{ F15 } & $\mathrm{O} / \mathrm{I}$ & 15. Value of the target species in traditional medicine & \\
\hline & & Surrounding population does not know about or believe in the medicinal value nowadays & 10.00 \\
\hline & & Known only by a very limited number of people (e.g., elderly, midwives. etc.) & 5.00 \\
\hline & & Widely known by the surrounding population & 0.00 \\
\hline \multirow[t]{5}{*}{ F16 } & $\mathrm{O} / \mathrm{I}$ & 16. Level of exploitation of the target species & \\
\hline & & Industrial exploitation & 10.00 \\
\hline & & Exploitation by the surrounding population & 6.66 \\
\hline & & Local exploitation & 3.33 \\
\hline & & Protected or unexploited & 0.00 \\
\hline \multirow[t]{4}{*}{ F17 } & $\mathrm{O}$ & 17. Distance from the site where the target species was found and the nearest path in the forest fragment & \\
\hline & & $<2 \mathrm{~m}$ & 10.00 \\
\hline & & $2-5 \mathrm{~m}$ & 5.00 \\
\hline & & $>5 \mathrm{~m}$ & 0.00 \\
\hline \multirow[t]{4}{*}{ F18 } & $\mathrm{O} / \mathrm{I}$ & 18. Conservation status in situ of the target species & \\
\hline & & Germplasm is not known nor found within any nearby protected area & 10.00 \\
\hline & & Germplasm is known and occurs within a protected area, but with insufficient or unknown conservation status & 5.00 \\
\hline & & Germplasm known and found within a protected area, with good conservation status. & 0.00 \\
\hline \multirow[t]{4}{*}{ F19 } & $\mathrm{O} / \mathrm{I}$ & 19. Conservation status ex situ of the target species & \\
\hline & & Germplasm is not known to be represented in any genebank & 10.00 \\
\hline & & Germplasm represented in a genebank, but the information available is poor, irregular or incomplete & 5.00 \\
\hline & & Germplasm represented in a genebank, with a satisfactory level of information available. & 0.00 \\
\hline \multirow[t]{5}{*}{ F20 } & $\mathrm{O}$ & 20. Cluster area & \\
\hline & & $<1 \mathrm{~m} 2$ & 10.00 \\
\hline & & $1-5 \mathrm{~m} 2$ & 5.00 \\
\hline & & $>5 \mathrm{~m} 2$ & 0.00 \\
\hline & & TOTAL SUM & $200=100 \%$ \\
\hline
\end{tabular}

Table 2. Sample size and ratio between floral morphs of four natural populations of Psychotria ipecacuanha in the state of Mato Grosso, Brazil. TAG: Tangará da Serra; BAB: Barra do Bugres; NOL: Nova Olímpia; DEN: Denise. (S) Short-styled; (L) Long-styled morphs.

\begin{tabular}{|c|c|c|c|c|c|}
\hline $\begin{array}{c}\text { Populations/ } \\
\text { Code }\end{array}$ & Number of clusters & $\begin{array}{c}\text { Total number of plants per } \\
\text { populations }\end{array}$ & \multicolumn{2}{|c|}{ Number of flowering plants } & Ratio between morphs \\
\hline TAG & 04 & 49 & 05 & 07 & $\chi^{2}=0.33 \mathrm{p}=0.56$ \\
\hline BAB & 05 & 52 & 16 & 14 & $\chi^{2}=0.13 \mathrm{p}=0.72$ \\
\hline NOL & 05 & 22 & 10 & 07 & $\chi^{2}=0.3 \mathrm{p}=0.47$ \\
\hline DEN & 10 & 90 & 19 & 11 & $\chi^{2}=2.13 \mathrm{p}=0.14$ \\
\hline
\end{tabular}

Table 3. Risk factors of genetic erosion observed in natural P. ipecacuanha in populations of the state of Mato Grosso, Brazil. TAG: Tangará da Serra; BAB: Barra do Bugres; NOL: Nova Olímpia; DEN: Denise.

\begin{tabular}{|c|c|c|c|c|c|c|c|c|c|c|c|c|c|c|c|c|c|c|c|c|c|c|}
\hline \multirow[b]{2}{*}{ Code } & \multicolumn{20}{|c|}{ Risk factors } & \multirow{2}{*}{ Total sum } & \\
\hline & F1 & F2 & F3 & F4 & F5 & F6 & F7 & F8 & F9 & F10 & $\mathbf{F} 11$ & F12 & F13 & F14 & F15 & F16 & F17 & F18 & F19 & F20 & & \\
\hline TAG & 6.66 & 10 & 10 & 10 & 5 & 10 & 0 & 10 & 0 & 5 & 6.66 & 10 & 5 & 10 & 5 & 5 & 10 & 5 & 5 & 5 & 133.32 & 66.66 \\
\hline BAB & 3.33 & 10 & 10 & 10 & 0 & 0 & 0 & 10 & 0 & 5 & 0 & 10 & 0 & 3.33 & 5 & 5 & 0 & 5 & 5 & 5 & 86.66 & 43.33 \\
\hline NOL & 3.33 & 10 & 10 & 10 & 10 & 10 & 0 & 10 & 0 & 5 & 0 & 10 & 10 & 10 & 5 & 0 & 10 & 5 & 5 & 10 & 133.33 & 66.67 \\
\hline DEN & 3.33 & 10 & 10 & 10 & 10 & 0 & 0 & 10 & 10 & 10 & 0 & 10 & 10 & 10 & 5 & 6.66 & 10 & 5 & 5 & 5 & 139.99 & 70.00 \\
\hline
\end{tabular}


of which were in the reproductive phase. In the population of Nova Olímpia, occupying a $41.6 \%$ smaller cluster area than the Denise population, 17 of the 22 plants found were in the reproductive phase (Tab. 2).

Significant differences in stamen and stigma height between short- and long-styled morphs $P$. ipecacuanha were recorded in all studied populations, reinforcing the distilia of the species (Tab. 4). Although the degree of reciprocity was not completely accurate between the stigma height and anther of alternative morphs among populations (Fig. 4 A-B), the reciprocity index proposed by Sánchez et al. (2013) was higher in populations where the corolla length was not significantly different among the floral morphs (Tab. 4), e.g., in Barra do Bugres and Nova Olimpia, with values of 0.91 and 0.85 respectively.

The reciprocity index of the Tangará da Serra population was 0.81 . In this population, the lowest degree of reciprocity was observed in stigma height of the short-styled morph in relation to stamen height of the long-styled morph (Tab. 4, Fig. 4). The reciprocity index of the population in Denise was 0.69 , which was $25 \%$ lower than that of the population in Barra do Bugres.

In all evaluated populations, the stigma lobes of the short-styled morphs were longer, and these differences were statistically significant (Denise: $\chi^{2}=11.20 ; p=0.0008$; Barra do Bugres: $\chi 2=18.85 ; \mathrm{p}=0.00001$; Tangará da Serra: $\chi 2=4.54$; $\mathrm{p}=0.03$; and Nova Olímpia: $\chi 2=7.70 ; \mathrm{p}=0.005$ ) (Tab. 4).

Our results suggest there is no direct relationship between large anther size and pollen production. In populations where the anther size was statistically different among floral morphs, e.g., those of Tangará da Serra and Barra do Bugres (Tab. 4), the pollen production was not high (Tab. 5). The pollen viability was high (> 79\%) in all studied populations (Tab. 5). The stigma receptivity was $100 \%$ for both floral morphs in all studied P. ipecacuanha populations.

\section{Discussion}

The P. ipecacuanha populations studied in the state of Mato Grosso are distributed in transition areas between the Amazon, Cerrado, and Pantanal biomes (Nascimento \& Ribeiro 2017). These three biomes host numerous plant and animal species threatened by extinction, and are affected by damage caused by anthropogenic action. As the pressure to open new areas is increasing, in order to increase meat and grain production for export, the natural resources of these regions are progressively depleted, in addition to the predatory exploitation of the region-specific plant germplasm (Skorupa \& Assis 1998).

Table 4. Flower morphology of short- and long-styled morphs in four natural populations of Psychotria ipecacuanha in Mato Grosso, Brazil. CL: Corolla length (mm); StiLL: Stigma lobe length (mm); AS: Anther size (mm); StyL: Style length (mm); StaH: Stamen height (mm). (S) Short-styled; (L) Long-styled morphs. $\mathrm{N}=20$.

\begin{tabular}{c|c|c|c|c|c|c|}
\hline Populations/ Code & CL \pm SD & StiLL \pm SD & AS \pm SD & StiH \pm SD & StaH \pm SD \\
\hline \multirow{2}{*}{ TAG } & $\mathrm{S}=9.57 \pm 0.54 \mathrm{a}$ & $\mathrm{S}=1.30 \pm 0.37 \mathrm{a}$ & $\mathrm{S}=1.97 \pm 0.11 \mathrm{a}$ & $\mathrm{S}=4.40 \pm 0.70 \mathrm{~b}$ & $\mathrm{~S}=8.80 \pm 0.71 \mathrm{a}$ \\
& $\mathrm{L}=8.70 \pm 0.47 \mathrm{~b}$ & $\mathrm{~L}=1.07 \pm 0.18 \mathrm{~b}$ & $\mathrm{~L}=1.47 \pm 0.11 \mathrm{~b}$ & $\mathrm{~L}=8.80 \pm 0.77 \mathrm{a}$ & $\mathrm{L}=4.87 \pm 0.36 \mathrm{~b}$ \\
\hline \multirow{3}{*}{$\mathrm{SAB}$} & $\mathrm{S}=7.27 \pm 0.52 \mathrm{a}$ & $\mathrm{S}=1.42 \pm 0.29 \mathrm{a}$ & $\mathrm{S}=1.70 \pm 0.25 \mathrm{a}$ & $\mathrm{S}=3.97 \pm 0.54 \mathrm{~b}$ & $\mathrm{~S}=6.87 \pm 0.79 \mathrm{a}$ \\
& $\mathrm{L}=6.95 \pm 0.62 \mathrm{a}$ & $\mathrm{L}=1.00 \pm 0.16 \mathrm{~b}$ & $\mathrm{~L}=1.47 \pm 0.11 \mathrm{~b}$ & $\mathrm{~L}=6.94 \pm 0.98 \mathrm{a}$ & $\mathrm{L}=3.92 \pm 0.33 \mathrm{~b}$ \\
\hline \multirow{2}{*}{ NOL } & $\mathrm{S}=8.82 \pm 1.01 \mathrm{a}$ & $\mathrm{S}=1.32 \pm 0.40 \mathrm{a}$ & $\mathrm{S}=1.65 \pm 0.23 \mathrm{a}$ & $\mathrm{S}=4.67 \pm 0.54 \mathrm{~b}$ & $\mathrm{~S}=7.85 \pm 1.07 \mathrm{a}$ \\
& $\mathrm{L}=8.30 \pm 1.48 \mathrm{a}$ & $\mathrm{L}=1.00 \pm 0.22 \mathrm{~b}$ & $\mathrm{~L}=1.55 \pm 0.15 \mathrm{a}$ & $\mathrm{L}=8.25 \pm 1.40 \mathrm{a}$ & $\mathrm{L}=4.75 \pm 0.69 \mathrm{~b}$ \\
\hline \multirow{2}{*}{ DEN } & $\mathrm{S}=9.52 \pm 0.47 \mathrm{a}$ & $\mathrm{S}=1.27 \pm 0.34 \mathrm{a}$ & $\mathrm{S}=1.85 \pm 0.23 \mathrm{a}$ & $\mathrm{S}=4.75 \pm 0.41 \mathrm{~b}$ & $\mathrm{~S}=8.45 \pm 0.42 \mathrm{a}$ \\
& $\mathrm{L}=8.62 \pm 0.35 \mathrm{~b}$ & $\mathrm{~L}=1.00 \pm 0.00 \mathrm{~b}$ & $\mathrm{~L}=1.85 \pm 0.23 \mathrm{a}$ & $\mathrm{L}=8.90 \pm 0.55 \mathrm{a}$ & $\mathrm{L}=4.87 \pm 0.22 \mathrm{~b}$ \\
\hline
\end{tabular}

Note: Different letters in a same populations indicate statistically significant differences ( $\mathrm{P}<0.05$ by the Scott-Knott test).

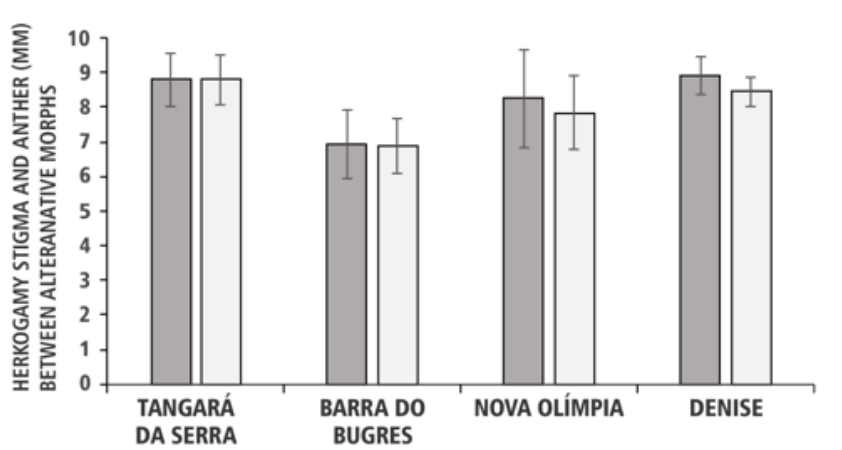

POPULATIONS

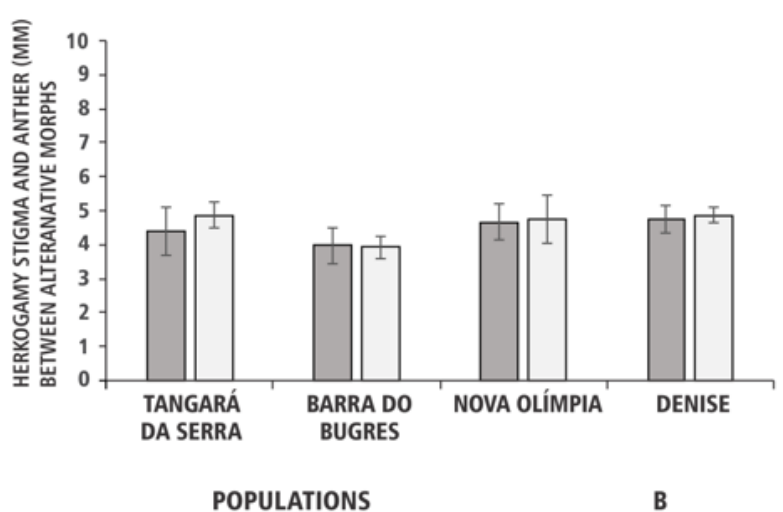

POPULATIONS

Figure 4. Hercogamy (mean values) between heights of stigma (dark bar) long styled vs anther (light bar) short styled (A); stigma (dark bar) short styled vs stamen (light bar) long styled (B) in populations of Psychotria ipecacuanha from four municipalities of Mato Grosso. The error bars refer to the standard deviation of the mean. 
Table 5. Pollen production and viability in flowers (\%) of the short-styled (S) and long-styled (L) morphs of Psychotria ipecacuanha in the state of Mato Grosso, Brazil.

\begin{tabular}{|c|c|c|c|c|c|c|c|c|}
\hline \multirow[b]{2}{*}{ Populations / Morphs } & \multicolumn{2}{|c|}{ Tangará da Serra } & \multicolumn{2}{|c|}{ Barra do Bugres } & \multicolumn{2}{|c|}{ Nova Olimpia } & \multicolumn{2}{|c|}{ Denise } \\
\hline & 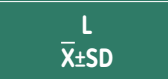 & $\underset{\bar{X} \pm S D}{S}$ & $\frac{\mathrm{L}}{\overline{\mathrm{X}} \pm S \mathrm{D}}$ & $\underset{\overline{\mathbf{X}} \pm S D}{S}$ & $\underset{\bar{X} \pm S D}{L}$ & $\underset{\bar{X} \pm S D}{S}$ & $\frac{L}{\bar{X} \pm S D}$ & $\underset{\bar{X} \pm S D}{S}$ \\
\hline Pollen production & $* 3.856 \pm 1.432$ & $1.961 \pm 367.5$ & $2.532 \pm 910.7$ & $2.866 \pm 580.9$ & $4.165 \pm 709.7$ & $2.821 \pm 1.278$ & $1.673 \pm 933.1$ & $1.420 \pm 463.8$ \\
\hline Pollen viability & $88.7 \pm 7.9$ & $90.5 \pm 5.3$ & $88.3 \pm 10.3$ & $94.8 \pm 2.2$ & $79.50 \pm 12.8$ & $83.3 \pm 6.8$ & $89.6 \pm 3.7$ & $86.2 \pm 7.6$ \\
\hline
\end{tabular}

Note: *Morphs differ significantly $(\mathrm{p}<0.05)$ by the $\chi^{2}$ test.

The clay soil texture of the forest fragments sampled from the state of Mato Grosso has also recorded in other studies, although P. ipecacuanha occurs mainly in sandy soils (Veloso 1947). The topography and slope of the land, the degree of acidity of the surface horizons, the quality of the drainage, the physical nature of the soil, and the of the vegetation cover influence the occurrence of the species (Veloso 1947).

Factors such as distance from the fragment to the largest population center and in situ and ex situ conservation status were major risk factors for the P. ipecacuanha populations in the Atlantic Forest (Oliveira \& Martins 2002). Habitat loss was observed inside and around the forest fragments studied, which was aggravated by the proximity of large agricultural areas, traces of logging and hunting, openings of clearings, and the presence of animals as cattle (personal observation). Habitat loss was one of the reasons for the low genetic diversity observed in natural populations of Psychotria hastisepala in the state of Minas Gerais (Silva \& Vieira 2013). In addition, habitat loss diminishes the areas of clusters, and can cause an imbalance in the ratio between morphs (anisoplethy), as well as reducing the number of physiologically mature plants for reproduction (Silva \& Segura 2015).

The isoplethy (Tab. 3) and reciprocity of reproductive intermorphic organs (Fig. 4) are important, and were confirmed in the study populations; however, they are not the only factor able to promote reproduction among the morphs of the species. Reproduction also depends on mechanisms associated with heteromorphic incompatibility, a system that prevents self-pollination between plants of the same morph (Barrett 2000), the effective action of pollinators (Silva et al. 2010), morphological variation among floral morphs (Silva \& Vieira 2015), and maintains the environmental characteristics required for species occurrence or persistence.

Isoplethy in P. ipecacuanha has been recorded (Rossi et al. 2005), in natural populations of the Atlantic Forest in Minas Gerais and Rio de Janeiro and is consistent with the results of the present study. For the genus Psychotria, isoplethy was also recorded in other distylous species such as P. tenuinervis (Virillo et al. 2007), P. brachypoda (Fonseca et al. 2008), P. carthagenensis (Koch et al. 2010; Faria et al. 2012); P. hastisepala (Silva \& Vieira 2015), P. elata (Silva \& Segura 2015), P. cephalophora (Watanabe et al. 2015), and P. deflexa (Matias et al. 2016).

Anther fixation to the corolla tube indicated, independent of the floral morph, a close relationship between corolla length and anther position. Given that reciprocal herkogamy promotes intermorph cross-pollination, morph differences in reproductive success may occur in populations where reciprocity of anthers and stigmas differs by the direction of pollen flow (Faivre \& McDade 2001; Armbruster et al. 2009; Valois-Cuesta et al. 2012) Based on morphometric, pollen production, and herkogamy characteristics, the populations of Barra do Bugres and Denise presented the best reproductive safety results in the present study.

In addition, we found that herkogamy was higher for the short-styled than the long-styled morphs in all populations, as previously reported for other Psychotria species (Sá et al. 2016) and Palicourea demissa (Valois-Cuesta et al. 2011). The absence of herkogamy between reproductive organs of short- and longstyled flowers generates the probability of self-pollination and asymmetric pollen flow (Perez-Barrales et al. 2014).

Asymmetric pollen flow could be promoted through the foraging activity of pollinators, which results in divergence between potential and realized functional genders, a fundamental process that may lead to functional dioecy (Valois-Cuesta et al. 2012). However, gender specialization requires confirmation, also considering several populations, because pollinators and other floral characteristics of the plants can vary among populations.

Longer stigma lobes in the short-styled morph may receive higher amounts of pollen than long-styled stigma in lobes (Barrett 2000). The different lengths of stigma lobes of the floral morphs of P. ipecacuanha confirms observations in other populations of the same species of the Atlantic Forest (Rossi et al. 2005), and other species such P. carthagenensis (Koch et al. 2010) and P. cephalophora (Watanabe et al. 2015).

Significant differences in the size of the short-styled anther, recorded in two populations of this study, may be related to the size of the pollen grains, which are generally larger in this morph (Virillo et al. 2007; Koch et al. 2010; Faria et al. 2012). Conversely, the long-styled morph, despite a smaller anther size, produced a significantly higher amount of pollen in at least one population. This greater pollen grain production, usually in long-flowered anthers, may compensate for asymmetric pollen flow between the floral forms, providing the stigmas of the less exposed shortstyled flowers with a greater pollen load (Ganders 1979).

The $>80 \%$ viability of pollen grains, a common characteristic of heterostylic species, has also been recorded in P. poeppigiana (Coelho \& Barbosa 2004), P. barbiflora (Teixeira \& Machado 2004), P. carthagenensis (Koch et al. 2010), P. conjugens, P. sessilis, P. hastisepala (Silva \& Vieira 
2013), and P. elata (Silva \& Segura 2015). This may assist in the reproductive success of the species (Valois-Cuesta et al. 2012).

Our results indicate a relatively low risk of genetic erosion in three of the four populations analyzed. Anthropogenic factors such as a reduced cluster size, low number of reproductive plants, habitat loss, and advance of the agricultural frontier jeopardize the maintenance of natural P. ipecacuanha populations in all analyzed populations.

The intensity of anthropogenic disturbances mainly influenced the population size of P. ipecacuanha. Three of the four populations evaluated presented a cluster area of less than $5 \mathrm{~m}^{2}$. Demographic stochasticity is an important factor leading to the local extinction of very small populations (Byers \& Meagher 1992), and Ipeca clusters are frequently isomorphic; that is, a given cluster exhibits either short- or long-styled flowers (Rossi et al. 2005).

Our studies corroborate the results presented by Oliveira et al. (2010), in 10 Ipeca populations occurring in the biomes of Atlantic Forest and Amazon. According to those authors, the Ipeca populations consisted of a handful of clusters and few populations contained more than six clusters.

The anthropogenic factors associated with morphological and reproductive characteristics, e.g., the low reciprocity between anther and stigma, and low pollen production, support risks for the maintenance and reproduction of Ipeca in the population of Denise-MT. Further studies addressing the frequency of pollinators and dispersers in the study areas are required.

\section{Acknowledgements}

This research was supported by a grant from the Fundação de Amparo à Pesquisa do Estado de Mato Grosso (FAPEMAT, process 159855/2014). Our sincere thanks to D. A. Costa, E. Aranda, and R. J. Silva for their technical support and to all members of the Botanical Laboratory.

\section{References}

Andersson L. 2002. Re-establishment of Carapichea (Rubiaceae, Psychotrieae). Kew Bulletin 57: 363-374.

Armbruster WS, Hansen TF, Pelabon C, Perez-Barrales R, Maad J. 2009. The adaptive accuracy of flowers: measurement and micro evolutionary patterns. Annals of Botany 103: 1529-1545.

Assis MC, Giulietti AM. 1999. Diferenciação morfológica e anatômica em populações de "ipecacuanha"-Psychotria ipecacuanha (Brot.) Stokes (Rubiaceae). Revista Brasileira de Botânica 22: 205-216.

Barrett SCH. 2000. The Evolution and function of stylar polymorphisms in flowering plants. Annals of Botany 85: 253-265.

Barrett SCH. 2002. The evolution of plant sexual diversity: Evolution of sex. Nature Reviews Genetics 3: 274-284.

Byers DL, Meagher TR. 1992. Mate availability in small populations of plant species with homomorphic sporophytic selfincompatibility. Heredity 68 353-359.

Coelho CP, Barbosa AAA. 2004. Biologia reprodutiva de Psychotria poeppigiana Mull. Arg. (Rubiaceae) em mata de galeria. Acta Botanica Brasilica 18: 481-489.
Crane PR. 2003. Measuring biodiversity for conservation. London, Royal Society.

Faivre AE, McDade LA. 2001. Population-level variation in the expression of heterostyly in three species of Rubiaceae: Does reciprocal placement of anthers and stigmas characterize heterostyly? American Journal of Botany 88: 841-845.

Faria RR, Ferrero V, Navarro L, Araujo AC. 2012. Flexible mating system in distylous populations of Psychotria carthagenensis Jacq. (Rubiaceae) in Brazilian Cerrado. Plant Systematics and Evolution 298: 619-627.

Ferrero V, Vega C, Stafford GI, Staden J, Johnson SD. 2009. Heterostyly and pollinators in Plumbago auriculata (Plumbaginaceae). South African Journal of Botany 75: 778-784.

Fonseca LCN, Almeida EM, Alves MAS. 2008. Phenology, floral morphology and visitors of Psychotria brachypoda (Müll. Arg.) Britton (Rubiaceae) in Atlantic Forest, southeastern Brazil. Acta Botanica Brasilica 22: 63-69.

Ganders FR. 1979. The biology of heterostyly. New Zealand Journal of Botany 17: 607-635.

Giraldo CB, Trujillo UAI, Naranjo Gómez EJ. 2015. Regeneration Potential of Psychotria ipecacuanha (Rubiaceae) from Thin Cell Layers. Acta Biológica Colombiana 20: 181-192.

Hodgins KA, Barrett SCH. 2008. Geographic variation in floral morphology and style-morph ratios in a sexually polymorphic daffodil. American Journal of Botany 95: 185-195.

Kearns CA, Inouye DW. 1993. Techniques for pollination biologists. Niwot, University Press of Colorado.

Kideghesho J, Røskaft E, Kaltenborn B, Tarimo T. 2005. Serengeti shall not die: Can the ambition be sustained? International Journal of Biodiversity Science, Ecosystems Services \& Management 1: 150-166.

Koch AK, Silva PC, Silva CA. 2010. Biologia reprodutiva de Psychotria carthagenensis (Rubiaceae), espécie distílica de fragmento florestal de mata ciliar, Centro-Oeste do Brasil. Rodriguésia 61: 551-558.

Matias R, Oliveira AS, Furtado MT, et al. 2016. Sistema reprodutivo atípico de duas espécies de Rubiaceae: distilia com autoincompatibilidade parcial no morfo brevistilo? Rodriguésia 67: 357-368.

Maxted N, Guarino L, Myer L, Chiwona EA. 2002 Towards a methodology for on-farm conservation of plant genetic resources. Genetic Resources and Crop Evolution 16: 31-46.

Nascimento DTF, Ribeiro SA. 2017. Os biomas brasileiros e a defesa da vida. Goiania, Kelps.

Oliveira LO, Martins ER. 2002. A quantitative assessment of genetic erosion in ipecac (Psychotria ipecacuanha). Genetic Resources and Crop Evolution 49: 607-617.

Oliveira LO, Venturini BA, Rossi AAB, Hastenreiter SS. 2010. Clonal diversity and conservation genetics of the medicinal plant Carapichea ipecacuanha (Rubiaceae). Genetics and Molecular Biology 33: 86-93.

Perez-Barrales R, Simon-Porcar VI, Santos-Gally R, Arroyo J. 2014. Phenotypic integration in style dimorphic daffodils (Narcissus, Amaryllidaceae) with different pollinators. Philosophical Transactions of the Royal Society B: Biological Sciences 369(1649): 20130258. doi.10.1098/rstb.2013.0258

R Development Core Team. 2014. R: A language and environment for statistical computing. Vienna, R Foundation for Statistical Computing.

Rossi AAB, Oliveira LO, Vieira MF. 2005. Distyly and variation in floral traits in natural populations of Psychotria ipecacuanha (Brot.) Stokes (Rubiaceae). Brazilian Journal of Botany 28: 285-294.

Sá T, Furtado MT, Ferrero V, et al. 2016. Floral biology, reciprocal herkogamy and breeding system in four Psychotria species (Rubiaceae) in Brazil. Botanical Journal of the Linnean Society 182: 689-707.

Sánchez JM, Ferrero V, Navarro L. 2008. A new approach to the quantification of degree of reciprocity in distylous (sensu lato) plant populations. Annals of Botany 102: 463-472.

Sánchez JM, Ferrero V, Navarro L. 2013. Quantifying reciprocity in distylous and tristylous plant populations. Plant Biology 15: 616620.

Silva CA, Segura JAL. 2015. Reproductive biology and herkogamy of Psychotria elata (Rubiaceae), a distylous species of the tropical rain forests of Costa Rica. American Journal of Plant Sciences 6: 433-444. 
Silva CA, Vieira MF, Amaral CH. 2010. Floral attributes, ornithophily and reproductive success of Palicourea longepedunculata (Rubiaceae), a distylous shrub in southeastern Brazil. Brazilian Journal of Botany 33: 207-213.

Silva CA, Vieira MF. 2013. Sucesso reprodutivo de espécies distílicas de Psychotria (Rubiaceae) em sub-bosque de floresta atlântica. Revista Árvore 37: 289297.

Silva CA, Vieira MF. 2015. Flowering and pollinators of three distylous species of Psychotria (Rubiaceae) co-occurring in the Brazilian Atlantic Forest. Revista Árvore 39: 779789.

Skorupa LA, Assis MC. 1998. Collection and conserving Ipecac (Psychotria ipecacuanha, Rubiaceae) germplasm in Brazil. Economic Botany 52: 209-210.

Teixeira LAG, Machado IC. 2004. Biologia da polinização e sistema reprodutivo de Psychotria barbiflora DC. (Rubiaceae). Acta Botanica Brasilica 18: 853-862.

Valois-Cuesta H, Pascual JS, Ornelas JF. 2011. Dimorphisms and selfincompatibility in the distylous species Palicourea demissa (Rubiaceae): possible implications for its reproductive output. Journal Plant Research 124:137-146. doi.org/ 10.1007/s10265-010-0359-9.
Valois-Cuesta H, Pascual JS, Ornelas JF. 2012. Gender specialization in Palicourea demissa (Rubiaceae), a distylous, hummingbird-pollinated treelet. Plant Systematics and Evolution 298: 975984

Veloso HP. 1947. As condiçoes ecologicas da Cephaelis ipecacuanha. Memórias do Instituto Oswaldo cruz 45: 361372.

Vieira RF, Silva SR, et al. 2002. Estratégias para conservação e manejo de recursos genéticos de plantas medicinais e aromáticas: resultados da $1^{a}$ reunião técnica. Brasília, Embrapa Recursos Genéticos e Biotecnologia.

Virillo CB, Ramos FN, Castro CC, Semir J. 2007. Floral biology and breeding system of Psychotria tenuinervis Muell. Arg. (Rubiaceae) in the Atlantic rain forest, SE Brazil. Acta Botanica Brasilica 21: 879884.

Watanabe K, Yang TYA, Nishihara C, et al. 2015. Distyly and floral morphology of Psychotria cephalophora (Rubiaceae) on the oceanic Lanyu (Orchid) Island, Taiwan. Botanical Studies 56: 4-9.

Zappi D, Jardim J, Souza EB, et al. 2013. Rubiaceae. In: Martinelli G, Moraes MA. (orgs.) Livro vermelho da flora do Brasil. 1st. edn. Rio de Janeiro, Andrea Jakobsson: Instituto de Pesquisas Jardim Botânico do Rio de Janeiro. p. 922-941. 